\title{
Impact of Fertilizer Doses on Growth and Yield in Elephant Footyam (Amorphophallus campanulatus) under Poplar (Populus deltoids) Based Agroforestry System
}

\author{
Anil Kumar* and B. Mehera \\ College of Forestry, Sam Higginbottom University of Agriculture Technology \& Sciences \\ Allahabad-211007, India \\ *Corresponding author
}

\section{A B S T R A C T}

\section{Keywords \\ Footyam, Poplar, Fertilizer dose, Collar diameter, Yield \\ Article Info \\ Accepted: \\ 26 January 2018 \\ Available Online: \\ 10 February 2018}

The field experimental study was conducted at Forest Nursery and Research farm, College of Forestry, Sam Higginbottom University of Agriculture Technology and Sciences, Allahabad during 2014 - 2016 to evaluate the impact of different fertilizer doses on Elephant Footyam (Amorphophallus campanulatus) under Poplar (Populus deltoids) based Agroforestry system. The experimental results observed in the present study at successive stage 225 DAP, application of $\mathrm{T}_{7}$ (Dose 80:60:140) produced significantly maximum plant height $(133.50 \mathrm{~cm})$, collar diameter $(7.46 \mathrm{~cm})$, canopy spread $(88.03 \mathrm{~cm})$ and total yam yield (33.07 tons/ha.) in open condition as well as at successive stage $225 \mathrm{DAS}$, under poplar based Agroforestry system application of $T_{7}$ (Dose 80:60:140)) produced significantly maximum plant height $(131.45 \mathrm{~cm})$, collar diameter $(7.42 \mathrm{~cm})$, canopy spread $(86.24 \mathrm{~cm})$ and total yam yield (32.06 tons/ha.)

\section{Introduction}

Agro-forestry is a collective name for land-use systems in which woody perennials (trees, shrubs, etc.) are grown in association with herbaceous plants (crops, pastures) and livestock in a spatial arrangement, a rotation or both, and in which there are both ecological and economic interactions between the tree and non-tree components of the system. The current approximate area under agroforestry is estimated to be $25.32 \mathrm{~m}$ ha, or $8.2 \%$ of the total geographical area of the country. Based on data from CAFRI, Jhansi, the area under agroforestry is 13.75 mha. However, Forest
Survey of India (FSI- 2013) estimated the same as $11.54 \mathrm{~m}$ ha, which is $3.39 \%$ of the geographical area of the country. Maharashtra, Gujarat and Rajasthan rank high in state-wise area under agroforestry Six indigenous species of poplars, viz., Populus ciliate, P. alba, $P$. euphratica, $P$. gamblii, $P$. jacquemontii var. glauca and $P$. rotundifolia are reported in India. Some experts consider $P$. alba and $P$. euphratica as exotics. $P$. deltoids has very high growth rate (mean annual increment of 20 to $25 \mathrm{~m}^{3} /$ ha/year) in India. The high productivity is achieved only when it is intercropped with such agricultural or horticultural crops as require intensive 
irrigation and other cultural operations. Research on agroforestry of this species was started by FRI Dehradun, Haldwani centre of state forest department and WIMCO in early 1960s. Cultivation of $P$. deltoides in agroforestry system by farmers started in 1970s.

Elephant foot yam (Amorphophallus campanulatus) an underground stem tuber, is one of the most popular tuber crops, extensively used as a favourite vegetable by millions of people in India. It has both nutritional and medicinal value and is usually consumed as cooked vegetable. Elephant foot yam is a remunerative and profitable stem tuber crop. The crop is gaining popularity due to its shade tolerance, easiness in cultivation, high productivity, less incidence of pests and diseases, steady demand and reasonably good price. Tubers are mainly used as vegetable after thorough cooking. Tubers contain $18.0 \%$ starch, $5 \%$ protein and up to $2 \%$ fat. Leaves contain $2-3 \%$ protein, $3 \%$ carbohydrates and 4-7 \% crude fibre. Tubers and leaves are quite acrid due to high content of oxalates.

Acridity is usually removed by boiling fairly for a long time. Cultivation of elephant foot yam is limited to India, Philippines, Sri Lanka and South East Asia. Unlike other tubers, Amorphophallus roots have many medicinal uses and are widely prescribed by Ayurvedic physicians.

\section{Materials and Methods}

The present study was carried out in Factorial RBD at Forest nursery \& research farm, College of Forestry, SHUATS, Allahabad (at an elevation of $25.41^{\circ} \mathrm{N}$ latitude and $81.84^{\circ} \mathrm{E}$ longitude, and 98 meter above the mean sea level.) Uttar Pradesh, India. It is located in the South-eastern part of Uttar Pradesh and has tropical to sub-tropical climate with extremes of summer and winter. During the winter months especially December and January, temperature drops down to as low as $5^{\circ} \mathrm{C}$, while in the summer temperature reaches above $45^{\circ} \mathrm{C}$, hot scorching winds (commonly known as Loo) is regular feature during the summers whereas there may be an occasional spell of frost during the winter. The annual rainfall is $1100 \mathrm{~mm}$ mostly during the monsoon autumn i.e. July to September, with a few occasional showers during the winter months. On the basis of field trial, field size is consisting of $108 \mathrm{~m}^{2}$ with three replications and nine treatments in association with Poplar (Populus deltoids) 15 years old, planted at $5 \times$ $5 \mathrm{~m}$ spacing were selected for the experiments of Elephant Footyam (Amorphophallus campanulatus). Planting material was procured from local market of Allahabad (UP) and bigger piece of corms were cut into pieces in $400 \mathrm{~g}$ size respectively for $A$. campanulatus. The material was subjected to treatment with Carbendazim@0.2\% by coating two layers over the surface of corm. Seed rate of $160 \mathrm{q} / \mathrm{ha}$ was used for $A$. campanulatus. The planting bed of $2 \times 2 \mathrm{~m}$ size was prepared and the distance kept for $A$. campanulatus was $60 \times 60$ $\mathrm{cm}$ (15-20 cm depth). Similar spacing was kept for both row to row and plant to plant. The FYM (Farm Yard Manure), vermicompost, and neemcake were added at the time of last ploughing and recommended dose of fertilizers were applied in the trial which was @ 80:60:100 kg/ha NPK for $A$. campanulatus. The rate was splitted in to three equal quantities and applied as a basal dose in March-April (Planting time), in July (vegetative and tillering stage) and in the last week of September (growth stage).

\section{Results and Discussion}

\section{Plant height}

There was a significant effect on the shoot height of Elephant footyam as affected by different fertilizer doses. 
Table.1 Plant Height (cm) of A. campanulatus (open \& under poplar) as influenced by different fertilizer doses under Poplar based Agroforestry system

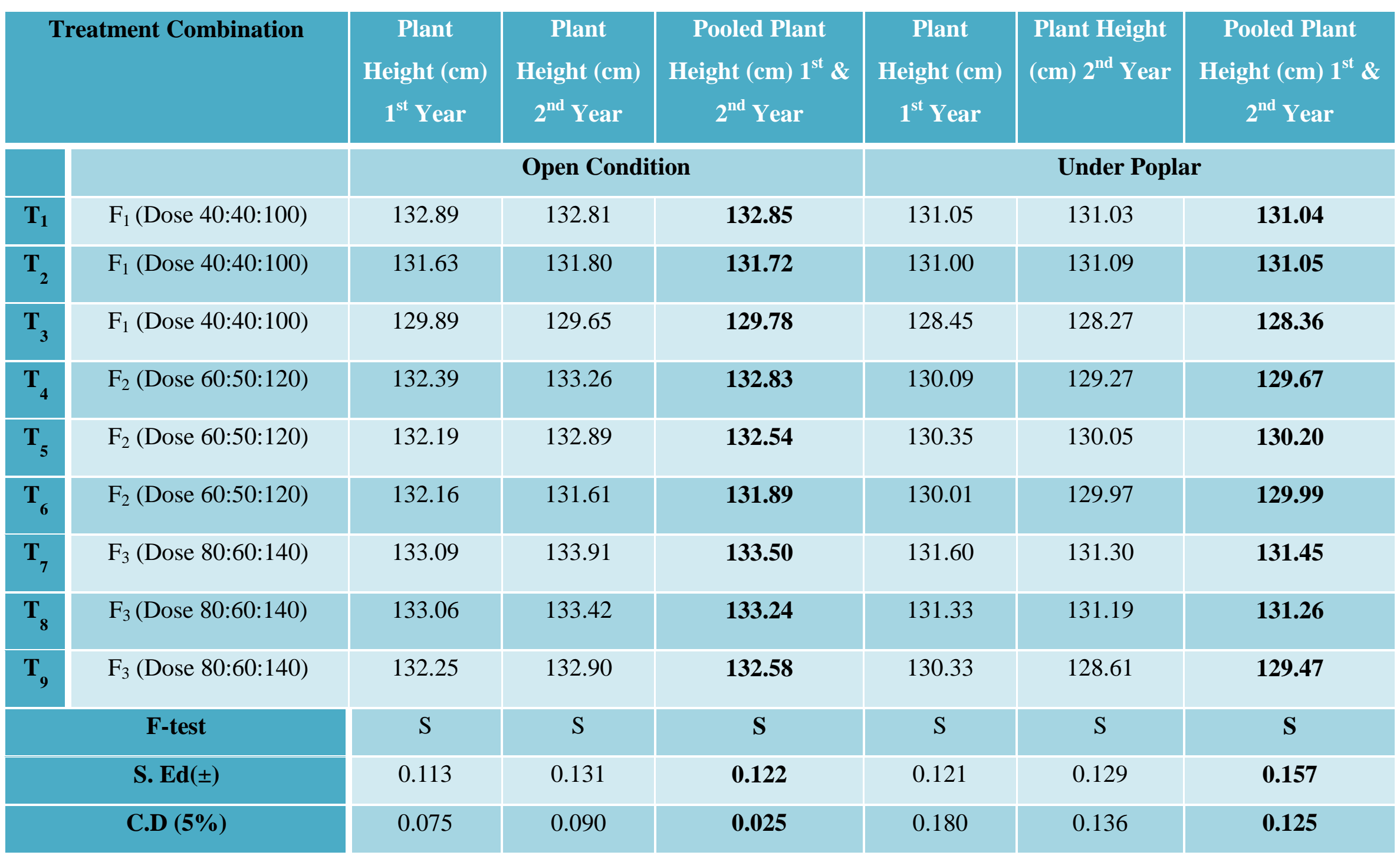

Method of Fertilizer application as Basal dressing. 
Table.2 Collar diameter of A. campanulatus (open \& under poplar) as influenced by different fertilizer doses under Poplar based Agroforestry system

\begin{tabular}{|c|c|c|c|c|c|c|c|}
\hline \multicolumn{2}{|c|}{ Treatment Combination } & $\begin{array}{c}\text { Collar } \\
\text { diameter } \\
\text { (cm) } 1^{\text {st }} \text { Year }\end{array}$ & $\begin{array}{c}\text { Collar } \\
\text { diameter } \\
(\mathrm{cm}) 2^{\text {nd }} \\
\text { Year }\end{array}$ & $\begin{array}{c}\text { Pooled } \\
\text { Collar } \\
\text { diameter } \\
(\mathrm{cm}) 1^{\text {st }} \& \\
2^{\text {nd }} \text { Year }\end{array}$ & $\begin{array}{c}\text { Collar } \\
\text { diameter } \\
(\mathrm{cm}) 1^{\text {st }} \\
\text { Year }\end{array}$ & $\begin{array}{c}\text { Collar } \\
\text { diameter } \\
(\mathrm{cm}) 2^{\text {nd }} \\
\text { Year }\end{array}$ & $\begin{array}{l}\text { Pooled Collar } \\
\text { diameter (cm) } \\
1^{\text {st }} \& 2^{\text {nd }} \text { Year }\end{array}$ \\
\hline & & \multicolumn{3}{|c|}{ Open Condition } & \multicolumn{3}{|c|}{ Under Poplar } \\
\hline $\mathrm{T}_{1}$ & $F_{1}($ Dose $40: 40: 100)$ & 7.41 & 7.45 & 7.43 & 7.35 & 7.41 & 7.38 \\
\hline $\mathrm{T}_{2}$ & $\mathrm{~F}_{1}($ Dose 40:40:100) & 7.42 & 7.44 & 7.43 & 7.36 & 7.41 & 7.39 \\
\hline $\mathbf{T}_{3}$ & $F_{1}($ Dose $40: 40: 100)$ & 7.36 & 7.41 & 7.39 & 7.31 & 7.37 & 7.34 \\
\hline $\mathbf{T}_{4}$ & $\mathrm{~F}_{2}($ Dose $60: 50: 120)$ & 7.43 & 7.44 & 7.44 & 7.36 & 7.41 & 7.39 \\
\hline $\mathbf{T}_{5}$ & $\mathrm{~F}_{2}($ Dose $60: 50: 120)$ & 7.40 & 7.42 & 7.41 & 7.34 & 7.39 & 7.37 \\
\hline $\mathrm{T}_{6}$ & $\mathrm{~F}_{2}($ Dose $60: 50: 120)$ & 7.39 & 7.42 & 7.41 & 7.35 & 7.40 & 7.38 \\
\hline$T_{7}$ & $\mathrm{~F}_{3}($ Dose $80: 60: 140)$ & 7.44 & 7.47 & 7.46 & 7.39 & 7.44 & 7.42 \\
\hline$T_{8}$ & $\mathrm{~F}_{3}($ Dose $80: 60: 140)$ & 7.44 & 7.46 & 7.45 & 7.38 & 7.43 & 7.41 \\
\hline $\mathbf{T}_{9}$ & $\mathrm{~F}_{3}($ Dose $80: 60: 140)$ & 7.38 & 7.44 & 7.41 & 7.36 & 7.42 & 7.39 \\
\hline & F-test & S & S & $\mathrm{S}$ & S & $\mathrm{S}$ & $S$ \\
\hline & S. Ed( $( \pm)$ & 0.001 & 0.004 & 0.001 & 0.002 & 0.004 & 0.249 \\
\hline & C.D (5\%) & 0.023 & 0.031 & 0.023 & 0.027 & 0.037 & 0.001 \\
\hline
\end{tabular}

Method of Fertilizer application as Basal dressing. 
Table.3 Canopy Spread of A. campanulatus (open \& under poplar) as influenced by different fertilizer doses under Poplar based Agroforestry system

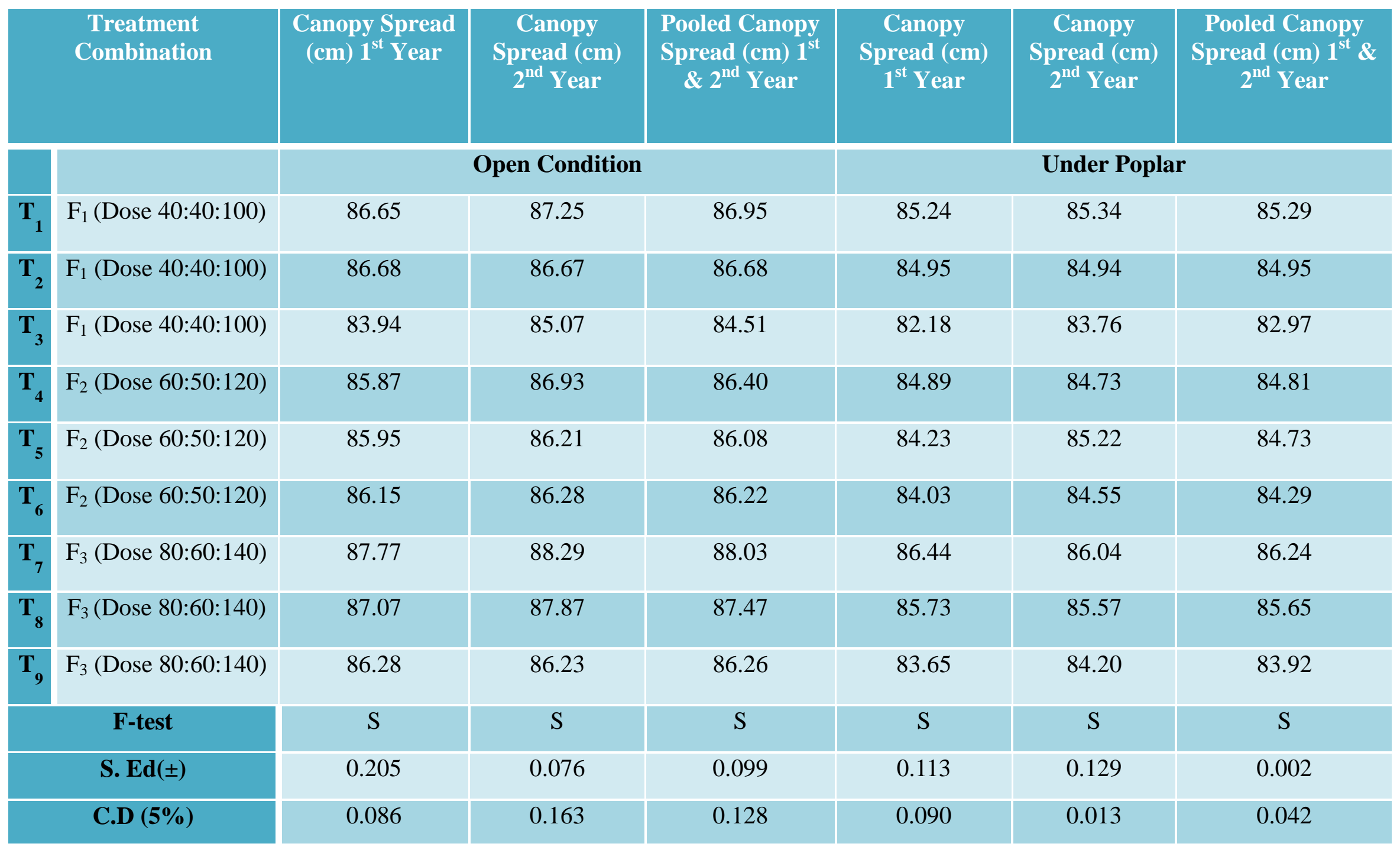

Method of Fertilizer application as Basal dressing. 
Table.4 Total yam yield of A. campanulatus (open \& under poplar) as influenced by different fertilizer doses under Poplar based Agroforestry system

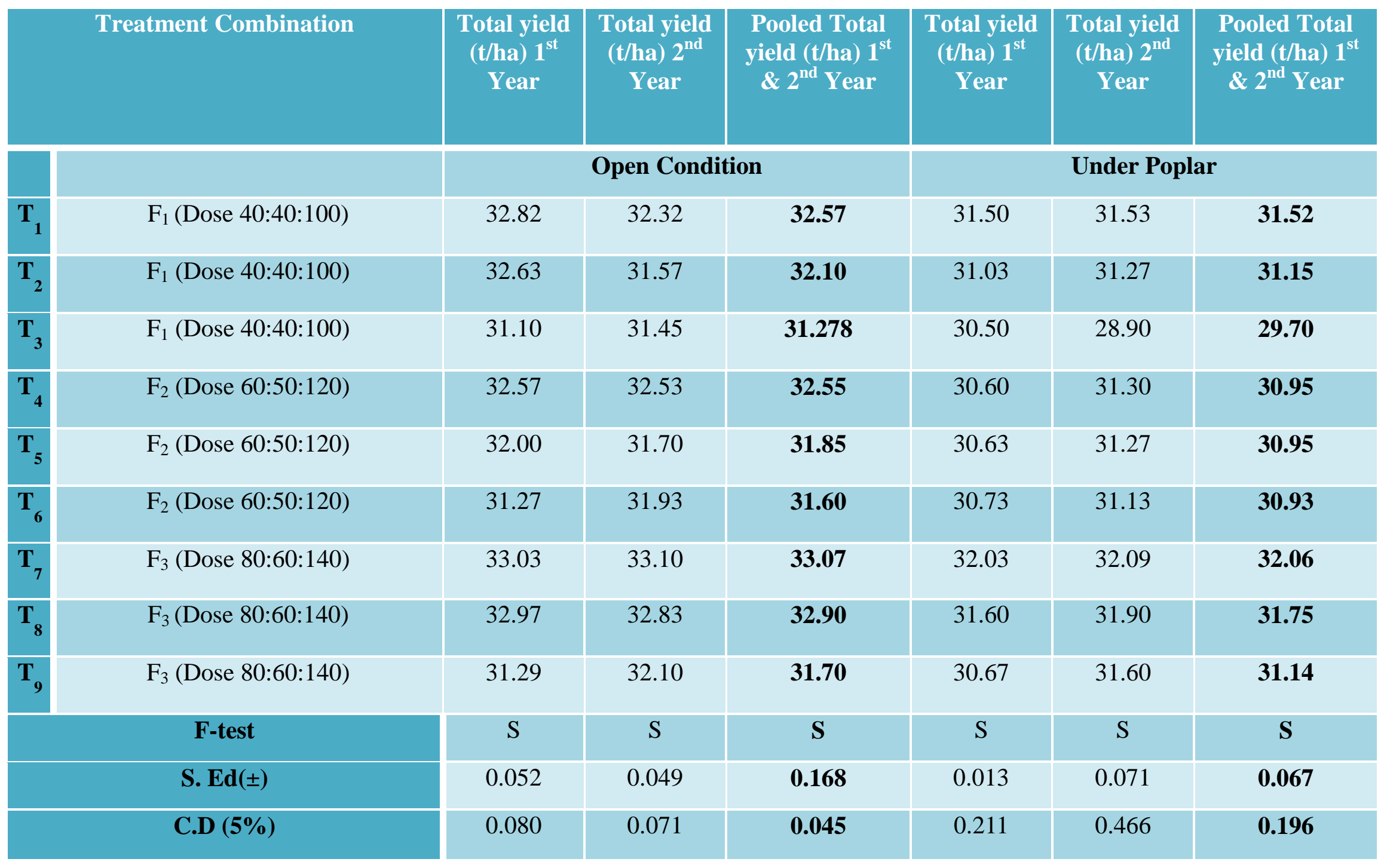


Plant height was found to be progressively increased with the treatment $\mathrm{T}_{7}$ (Dose 80:60:140) compared to other fertilizer doses (Table 1). According to the pooled data of the year 2014 -16 maximum plant height was observed in $\mathrm{T}_{7}(133.50 \mathrm{~cm})$ followed by $\mathrm{T}_{8}$ $(133.24 \mathrm{~cm})$ and minimum plant height recorded in $\mathrm{T}_{3}(129.78 \mathrm{~cm})$ in open area, whereas under poplar maximum plant height was recorded in $\mathrm{T}_{7}(131.45 \mathrm{~cm})$ followed by $\mathrm{T}_{8}(131.26 \mathrm{~cm})$ and minimum plant height recorded in $\mathrm{T}_{3}(128.36 \mathrm{~cm})$ simultaneously. Similar results were reported by Narwal et al., 1993. There was a significant effect of different fertilizer doses on the growth and yield of Turmeric.

\section{Collar diameter}

It is revealed that in pooled data of various treatment combinations there was significant effect on collar diameter as compared. At successive stage the maximum collar diameter was recorded in $\mathrm{T}_{7}(7.46 \mathrm{~cm})$ followed by $\mathrm{T}_{8}$ $(7.45 \mathrm{~cm})$ and minimum collar diameter found in $\mathrm{T}_{3}(7.39 \mathrm{~cm})$ in open area, whereas under poplar maximum collar diameter was recorded in $\mathrm{T}_{7}(7.42 \mathrm{~cm})$ followed by $\mathrm{T}_{8}(7.41$ $\mathrm{cm})$ and minimum collar diameter recorded in $\mathrm{T}_{3}(7.34 \mathrm{~cm})$ simultaneously (Table 2). Similar findings were also reported by Nedunchezhiyan (2008).

\section{Canopy spread}

There was a significant difference in canopy spread (the radial expansion of the leaf) among the crop grown with the association of different fertilizer doses. The highest spread of canopy in Elephant footyam was recorded in $\mathrm{T}_{7}(88.03 \mathrm{~cm})$ followed by $\mathrm{T}_{8}(87.47 \mathrm{~cm})$ and minimum spread of canopy found in $\mathrm{T}_{3}$ $(84.51 \mathrm{~cm})$ in open area, whereas under poplar maximum spread of canopy was recorded in $\mathrm{T}_{7}(86.24 \mathrm{~cm})$ followed by $\mathrm{T}_{8}$ $(85.65 \mathrm{~cm})$ and minimum spread of canopy in
$\mathrm{T}_{3}(82.97 \mathrm{~cm})$ simultaneously (Table 3$)$. The canopy spread was more in plants raised by planting whole seed corms than that in plants produced from cut pieces of corms of the same size (Das et al., 1997).

\section{Yield of elephant footyam}

There was a significant effect of different doses recorded in the total yield of Elephant footyam. It is revealed that maximum yield was recorded in $\mathrm{T}_{7}(33.07 \mathrm{t} / \mathrm{ha})$ followed by $\mathrm{T}_{8}$ (32.90 t/ha) and minimum yield was found in $\mathrm{T}_{3}$ (31.278 $\left.\mathrm{t} / \mathrm{ha}\right)$ in open area, whereas under poplar maximum yield was recorded in $\mathrm{T}_{7}(32.06 \mathrm{t} / \mathrm{ha})$ followed by $\mathrm{T}_{8}(31.75 \mathrm{t} / \mathrm{ha})$ and minimum yield was recorded in $\mathrm{T}_{3}(29.70$ t/ha) simultaneously (Table 4). Das and Maharana 1995 reported that elephant footyam does not compete for light as because this crop is able to tolerant shade. It was also observed that the inclusion of any of the companion crops reduce the yield of main crop. Similar results were obtained by Kumar et al., 1973 who revealed that the corm yield of elephant foot yam had significant positive correlations with starch content, plant height, and weight of individual corm, size of individual corm, stem girth, canopy spread and dry matter. These findings are in conformity with the results reported by Abbey et al., 2000 also reported similar results. This may also be due to congenial climatic Conditions. These findings are reported by Patel et al., (2011).

In view of the experimental results observed in the present study, application of $\mathrm{T}_{7}$ (Dose 80:60:140) produced significantly maximum plant height, collar diameter, canopy spread and yield in elephant foot yam followed by $\mathrm{T}_{8}$ (Dose 80:60:140) as comparison to other fertilizer doses (Dose 60:50:120 and Dose $40: 40: 100)$. So it may be concluded that it is economically dose 80:60:140 $\quad\left(\mathrm{T}_{7}\right)$ with Gajendra is the best combination for the 
production of Elephant footyam under Poplar based agroforestry system but before giving final recommendations, multi-location trials should be conducted with this treatment combinations as far as planting conditions concerned.

\section{References}

Abbey, L., Joyce, D.C., Aked, J. and Smith, B., (2000) Genotype, sulphur Nutrition and Soil Type Effect on growth and Dry matter production of Spring Onion. J. Hort. Sci. and Biontech. 77 (3): pp. 340345.

Das PK, Sen H, Banerjee NC, Penda PK 1997: Growth analysis and dry matter partitioning of elephant foot yam (Amorphophallus paeoniifolius) under different plant densities and sett sizes. Indian Journal of Agricultural Sciencess 67(5) 197-200.

Das, A.K. and Maharana, T. 1995. Effect of spacing and intercropping on bunch characters of banana cV. Robusta. The Orissa Journal of Horticulture, 23 (1-2): 13-17

Kumar CRM, Mandal RC and Singh KD 1973. Effect of mulching and plant density on growth, yield and quality of Amorphophallus. Indian Journal of Agronomy 18(1): 62-66.

Narwal, A. K., Khurana, S. C. and Pandita, M. L. 1993. Effect of plant growth substances, tuber sizes and removal of sprouts on growth, yield and multiplication rate of potato. J. Indian Potato Assoc., 20 (3\&4): 223-229.

Nedunchezhiyan, M. 2008. Seed corm production techniques in elephant foot yam. Orissa Review 65: 64-66.

Patel, J. C., Patel, N. B., Saravaiya, S. N., Desai, K. D. and Tekale, G. S. 2011.Effect of spacing and corm size on growth and yield of Elephant foot yam under south Gujarat conditions. Journal of root crops. Vol. 37 No.1, pp. 88-89.

Raj pal singh*, s. Bhushan, Santosh kumar and Ravi Shanker 2013. Yield assessment of elephant foot yam grown under multilayer vegetable cropping system. The Bioscan, 8(4): 1237-1239, 2013

Ravindran, C.S., Nair, M. and Nedunchezhiyan, 2006. Intercropping tuber crops is remunerative. Indian Horticulture, 51 (6): 25-27.

\section{How to cite this article:}

Anil Kumar and Mehera, B. 2018. Impact of Fertilizer Doses on Growth and Yield in Elephant Footyam (Amorphophallus campanulatus) under Poplar (Populus deltoids) Based Agroforestry System. Int.J.Curr.Microbiol.App.Sci. 7(02): 3261-3268.

doi: https://doi.org/10.20546/ijcmas.2018.702.391 